\title{
ANALISIS FAKTOR-FAKTOR YANG MEMPENGARUHI TINGKAT PENGANGGURAN DI SULAWESI UTARA PADA MASA PANDEMI COVID-19 TAHUN 2020
}

\author{
Fitria Norma Aula Zahro \\ Email: 18611086@students.uii.ac.id \\ Program Studi Statistika Fakultas MIPA Universitas Islam Indonesia \\ Faried Abimanyu \\ Email: 18611089@students.uii.ac.id \\ Program Studi Statistika Fakultas MIPA Universitas Islam Indonesia \\ Aprin Nurfika Azhar \\ Email: 18611090@students.uii.ac.id \\ Program Studi Statistika Fakultas MIPA Universitas Islam Indonesia \\ Edy Widodo \\ Email: edywidodo@uii.ac.id \\ Program Studi Statistika Fakultas MIPA Universitas Islam Indonesia
}

\begin{abstract}
ABSTRAK
Pada tahun 2020, pandemi Corona Virus Disease menyebabkan pertumbuhan ekonomi dunia mengalami penurunan, termasuk Indonesia. Berdasarkan data Badan Pusat Statistik (BPS), Provinsi Sulawesi Utara masuk ke dalam 10 besar dengan jumlah tingkat pengangguran tertinggi di Indonesia dan naik sebesar 1.36\% jika dibandikan dengan Agustus 2019. Penelitian ini bertujuan untuk mengetahui pengaruh Pertumbuhan PDRB, Angka Harapan Hidup (AHH), Rata-Rata Lama Sekolah (RLS), dan Jumlah Penduduk terhadap Tingkat Pengangguran di Provinsi Sulawesi Utara Tahun 2020 menggunakan metode regresi linier berganda. Dari hasil analisis diketahui bahwa variabel RLS dan jumlah penduduk berpengaruh positif dan signifikan pada tingkat pengangguran di Sulawesi Utara tahun 2020, dengan diperoleh nilai $\mathbf{R}^{2}$ sebesar $\mathbf{7 3 . 6 1 \%}$ yang menunjukkan perbandingan dari pengaruh variabel bebas terhadap variabel terikat sedangkan sisanya yaitu bernilai $26.39 \%$ dipengaruhi oleh variabel lain yang tidak terdapat atau diluar pada model regresi linier.
\end{abstract}

Kata Kunci: Tingkat Pengangguran, Coronavirus Disease, Regresi Linear Berganda

\section{ABSTRACT}

In 2020, the Corona Virus Disease pandemic caused world economic growth to decline, including Indonesia. Based on data from the Badan Pusat Statistik (BPS), North Sulawesi Province is in the top 10 with the highest unemployment rate in Indonesia and an increase of $1.36 \%$ when compared to August 2019. This study aims to determine the effect of PDRB Growth, Life Expectancy (AHH), Mean Years School (RLS), and Total Population to Unemployment Rate in North Sulawesi Province in 2020 using the multiple linear regression method. From the results of the analysis, it is found that the RLS variable and the population have a positive and significant effect on the unemployment rate in North Sulawesi in 2020, with an $R^{2}$ value of $73.61 \%$ which shows the proportion of the influence of the independent variable on the dependent variable while the remaining $26.39 \%$ is influenced by other variables. which is not present or outside the linear regression model.

Keyword : Unemployment Rate, Coronavirus Disease, Multiple Linear Regression 


\section{PENDAHULUAN}

Pada awal tahun 2020, pertumbuhan ekonomi Indonesia terjadi penurunan. Hal itu dipengaruhi oleh pandemi Covid-19 yang sedang terjadi di Indonesia dan menyebabkan para pekerja tidak memiliki pekerjaan tetap, berhenti bekerja. Hal tersebut berdampak pada pendapatan masyarakat menurun yang menyebabkan pendapatan nasional juga akan menurun. Sehingga yang terjadi pertumbuhan ekonomi akan melemah (Indayani \& Hartono, 2020). Berdasarkan data Badan Pusat Statistik (2021), penurunan perekonomian Indonesia tahun 2020 diukur berdasarkan Produk Domestik Bruto (PDB) dapat dilihat pada grafik gambar di bawah ini.

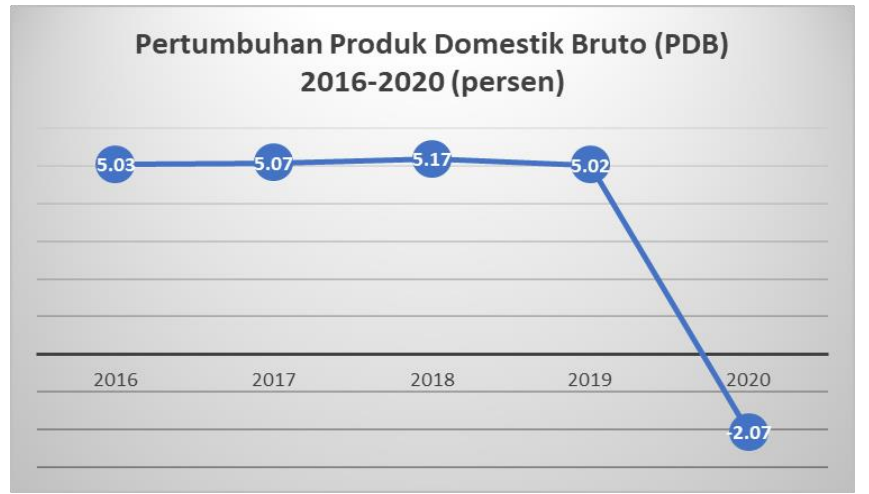

Gambar 1. Grafik Pertumbuhan Produk Domestik Bruto (PDB)

Untuk menilai kinerja suatu perekonomian dapat melihat indikator yang sangat penting salah satunya pertumbuhan ekonomi disuatu negara atau daerah tersebut. Apabila produksi barang dan jasa meningkat dari tahun sebelumnya maka pertumbuhan ekonomi di wilayah tersebut bertumbuh baik, seperti aktivitas perekonomian yang dapat menghasilkan tambahan pendapatan atau kesejahteraan masyarakat pada suatu periode. Pertumbuhan ekonomi di suatu negara atau wilayah yang terus memperlihatkan kenaikan yang menjelaskan bahwa perekonomian negara atau wilayah itu meningkat dengan baik (Murahni, 2019).

Salah satu melihat keberhasilan pembangunan ekonomi pada suatu negara dapat melihat indikator perekonomian yaitu tingkat pengangguran. Kondisi suatu negara berdasarkan tingkat pengangguran dapat dilihat perekonomiannya berkembang atau mengalami penurunan. Pengangguran sendiri yaitu sebuah kondisi ketika seseorang belum memperolah dan menemukan pekerjaan yang tergolong dalam angkatan kerja mereka (Sukirno, 2008). 
Pengangguran masih menjadi masalah yang dihadapi oleh negara Indonesia. Indonesia sebagai negara berkembang perlu melaksanakan berbagai perubahan agar mendukung pembangunan nasional. Hal ini bertujuan agar stabilitas nasional tercipta, pertumbuhan ekonomi di dalam negri tinggi, dan musim investasi yang baik, hal tersebut dapat menekan angka pengangguran di Indonesia.

Angka pengangguran meningkat seiring dengan menurunnya pertumbuhan ekonomi Indonesia salah satunya terjadi di Provinsi Sulawesi Utara yang merupakan tingkat pengangguran tertinggi di Indonesia. Menurut Badan Pusat Statistik (BPS) Sulawesi Utara (Sulut), pada Agustus 2020 jumlah angkatan kerja tercantum ada 1.23 juta orang dan yang bekerja sebanyak 1.13 juta orang. Tingkat Pengangguran Terbuka 7.37\% atau meningkat sebesar 1.36\% jika dibandingkan Agustus 2019 (Statistik \& Gorontalo, 2020).

Meningkatnya tingkat pengangguran sangat dipengaruhi oleh pandemi Covid-19. Hal itu mengakibatkan perekonomian di Indonesia semakin terpuruk. Dampak dari pandemi Covid-19 juga menyebabkan angka pengangguran di Indonesia meningkat akibat dari banyaknya PHK di masa pandemi ini. Jumlah penduduk dengan tingkat pengangguran dapat diketahui hubungannya berdasarkan teori Malthus dalam masyarakat modern disebutkan bahwa pertambahan jumlah penduduk akan mengakibatkan meningkatnya tenaga kerja, tetapi tidak diikuti oleh kesempatan kerja yang tersedia. Kemudian indikator kualitas penduduk dapat diukur berdasarkan Angka harapan Hidup (AHH) juga mempengaruhi pengangguran (Chalirafi, dkk, 2020). Di sisi lain, dalam studi mengenai PDRB disebutkan bahwa PDRB yang mengalami peningkatan diprediksi dapat menyerap tenaga kerja, sebab dengan naiknya PDRB berpotensi meningkatkan kapasitas produksi (Muslim, 2014).

Indikator lain yaitu pendidikan tentunya sangat berpengaruh pada tingkat pengangguran. Pendidikan ditentukan berdasarkan Rata-rata Lama Sekolah (RLS). Salah satu cara untuk meningkatkan kemampuan logika manusia yaitu pendidikan, dikarenakan adanya persaingan yang ketat dan kemajuan teknologi (Husila, 2019). Pendidikan dapat memudahkan sumber daya manusia dalam mencari pekerjaan karena mempunyai nilai daya saing yang tinggi dan berakibat pada berkurangnya tingkat pengangguran. Oleh karena itu perlu dilakukan analisis faktor-faktor yang mempengaruhi tingkat pengangguran di Provinsi Sulawesi Utara tahun 2020 dikarenakan terdapat dugaan bahwa pandemi COVID-19 yang terjadi pada tahun 2020 mempengaruhi faktor-faktor yang menyebabkan tingkat 
pengangguran bertambah. Dalam menganalisis faktor-faktor tersebut peneliti menggunakan metode regresi linier berganda.

\section{METODE PENELITIAN}

Data yang digunakan yaitu data sekunder yang terdiri dari data Tingkat Pengangguran, pertumbuhan PDRB, Angka Harapan Hidup (AHH), Rata-rata Lama Sekolah (RLS), dan Jumlah Penduduk Provinsi Sulawesi Utara yang di dapatkan dari situs https://sulut.bps.go.id/. Metode pengumpulan data pada penelitian ini menggunakan cara observasi yaitu mengamati objek yang diteliti. Dari observasi diperoleh data berupa data sekunder atau data yang diperoleh dari pihak lain (sudah tersedia) dan telah diolah menjadi bentuk publikasi.

Definisi operasional variabel dari Tingkat Pengangguran (Y) adalah Tingkat Pengangguran Terbuka di suatu Kabupaten/Kota tertentu. Kemudian variabel Pertumbuhan PDRB $\left(\mathrm{X}_{1}\right)$ merupakan rasio pertumbuhan dalam bentuk bilangan persentase diturunkan dari perhitungan PDRB adhk. Selanjutnya variabel AHH $\left(\mathrm{X}_{2}\right)$ adalah rata-rata jumlah tahun yang dijalani oleh seseorang setelah orang itu mencapai ulang tahun yang ke-x. Variabel RLS $\left(\mathrm{X}_{3}\right)$ merupakan jumlah tahun yang digunakan oleh penduduk dalam menjalani pendidikan formal. Sedangkan variabel Jumlah Penduduk $\left(\mathrm{X}_{4}\right)$ merupakan Jumlah Penduduk di suatu Kabupaten/Kota tertentu.

Dalam penelitian ini peneliti metode analisis data berupa analisis deskriptif dan analisis regresi linier berganda dengan alat bantu software RStudio. Berikut merupakan tahapan dalam melakukan penelitian menggunakan metode analisis regresi berganda yang digambarkan melalui diagram alir. 


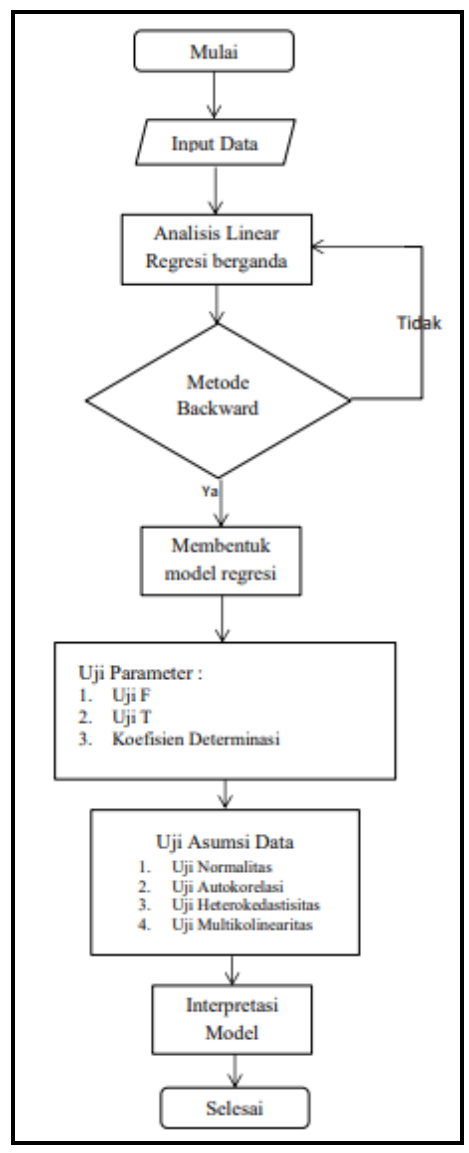

Gambar 2. Diagram Alir Penelitian

\section{Analisis Regresi Linier Berganda}

Pengaplikasikan analisis regresi linier berganda untuk menemukan relasi linier dari dua atau lebih variabel terikat $\left(\mathrm{X}_{1}, \mathrm{X}_{2}, \ldots, \mathrm{X}_{\mathrm{k}}\right)$ dan juga variabel bebas $(\mathrm{Y})$. Analisis regresi linier berganda bertujuan yaitu mendapatkan prediksi nilai variabel tak bebas (Y) terhadap nilai variabel bebasnya $\left(\mathrm{X}_{1}, \mathrm{X}_{2}, \ldots \mathrm{X}_{\mathrm{k}}\right)$ dan juga untuk melihat hubungan variabel bebas dan tak bebas (Ningsih \& Dukalang, 2019). Adapun persamaan regresi linier berganda secara matematik ditunjukkan sebagai berikut :

$$
Y=\beta_{0}+\beta_{1} x_{1}+\beta_{2} x_{2}+\ldots \beta_{k} X_{k}+\varepsilon
$$

\section{Metode Pemilihan Model}

Pemilihan model terbaik dilakukan menggunakan metode backward. Metode Backward mencari variabel $\mathrm{X}$ dan variabel $\mathrm{Y}$ yang diregresikan dengan langkah mundur. Eliminasi pada variabel $\mathrm{X}$ berdasarkan pada nilai parsial paling kecil dan menentukan variabel X pada model oleh nilai F (Samosir, dkk, 2014). 


\section{Uji Signifikansi Parameter}

1. Uji Overall (F-test)

Penggunaan uji Overall (F-Test) yaitu agar mengetahui model variabel independen apakah terdapat pengaruh secara signifikan terhadap variabel dependennya atau tidak (Ghozali, 2018).

Hipotesis uji $\mathrm{F}$ :

$\mathrm{H}_{0}$ : (Model tidak layak digunakan)

$\mathrm{H}_{1}$ : (Model layak digunakan)

2. Uji Parsial (t-test)

Uji Parsial (t-test) dilakukan dalam menentukan pengaruh secara individual satu variabel independen untuk menjelaskan variasi veriabel dependen.

Hipotesis Uji t :

$\mathrm{H}_{0}: \beta \mathrm{i}=0$, di mana $\mathrm{i}=0,1, \ldots \mathrm{k}$

$\mathrm{H}_{1}: \beta \mathrm{i} \neq 0$, di mana $\mathrm{i}=0,1, \ldots \mathrm{k}$

\section{Uji Koefisien Determinasi $\left(\mathbf{R}^{2}\right)$}

Kekuatan model dalam menguraikan variabel terikat diukur memakai koefisien determinasi atau dinotasikan dengan $\mathrm{R}^{2}$. Semakin tinggi variabel bebas dalam menguraikan variasi variabel terikat maka semakin tinggi perhitungan adjusted $\mathrm{R}^{2}$ (Ghozali, 2016).

\section{Uji Asumsi Klasik}

Uji asumsi klasik pada analisis regresi linier berganda menggunakan metode ordinary least square (OLS). Untuk melakukan analisis regresi diperlukan asumsi-asumsi residual yang harus dipenuhi.

1. Uji Normalitas

Tujuan dari uji normalitas agar diketahui ada atau tidaknya distribusi normal pada model regresi, variabel dependen dan variabel independen. Model yang mempunyai distribusi data normal merupakan model regresi yang baik. Untuk melakukan uji normalitas menggunakan uji Kolmogorov-Smirnov (Ghozali, 2016).

$H_{0} \quad$ : Data berdistribusi normal

$H_{1} \quad$ : Data tidak berdistribusi normal

Apabila $p$-value $<\alpha$, tolak $H_{0}$ artinya data tidak berdistribusi normal. Jika uji asumsi terpenuhi, maka harus gagal tolak $H_{\emptyset}$. 
2. Uji Autokorelasi

Tujuan uji autokorelasi yaitu untuk menunjukkan ada atau tidak korelasi antar dua variabel independen atau lebih pada model regresi berganda (Hidayat, 2017). Model regresi dapat dikatakan baik jika autokorelasi nya tidak ada. Metode yang digunakan yaitu dengan menggunakan uji Durbin Watson.

$H_{0} \quad$ : Tidak terdapat autokorelasi pada residual

$H_{1} \quad$ : Terdapat autokorelasi pada residual

Apabila $p$-value $<\alpha$, tolak $H_{0}$ artinya terdapat autokorelasi. Jika uji asumsi terpenuhi, maka harus gagal tolak $H_{0}$.

3. Uji Heteroskedastisitas

Uji heteroskedastisitas untuk mendapati keterjadian perbedaan varian sisa dalam model regresi dari observasi pada observasi lainnya. Dalam penelitian studi kasus ini uji heteroskedastisitas yang digunakan dengan uji Breusch Pagan (Hidayat, 2017).

$H_{0} \quad$ : Tidak terjadi heteroskedastisitas

$H_{1} \quad$ : Terjadi heteroskedastisitas

Apabila $p$-value $<\alpha$, tolak $H_{0}$ artinya terjadiheteroskedastisitas. Jika uji asumsi terpenuhi, maka harus gagal tolak $H_{0}$.

4. Uji Multikolinearitas

Tujuan uji multikolinearitas yaitu untuk mendapati ketersediaan relasi variabel yang ada di model prediksi diketahui melalui nilai Variance Inflation Factor (VIF) dan nilai tolerance. Terjadinya multikolinearitas apabila nilai VIF $\geq 10$ dan nilai toleransi $<0.1$ (Ghozali, 2013).

$H_{0} \quad$ : Tidak terdapat multikolinearitas

$H_{1} \quad$ : Terdapat multikolinearitas

\section{HASIL DAN PEMBAHASAN}

\section{Analisis Deskriptif}

Analisis deskriptif memberikan gambaran suatu data seperti mean, median, modus, varians, dan lainnya. Analisis deskriptif bertujuan untuk melihat penyebaran data sampel atau populasi. Berdasarkan data, dapat diketahui bahwa gambaran atau penyebaran sampel atau populasi jumlah pengangguran di setiap wilayah Provinsi Sulawesi Utara tahun 2020 yang paling tinggi terdapat pada wilayah Kota Manado sebesar $13.88 \%$ dan disusul oleh 
Kota Bitung sebesar $10.23 \%$. Sedangkan tingkat pengangguran terendah terdapat pada Kepulauan Talaud yaitu sebesar $2.64 \%$. Selanjutnya untuk gambaran dari setiap faktor yang mempengaruhi tingkat pengangguran tampak pada tabel berikut.

Tabel 1. Tabel hasil analisis deskriptif program $R$

\begin{tabular}{ccccc}
\hline Variabel & N & Min & Max & Standar Deviasi \\
\hline Tingkat Pengangguran & 15 & 2.640 & 13.880 & 2.900 \\
$(\%)$ & & & & \\
Pertumbuhan PDRB (\%) & 15 & -0.89 & 0.17 & 0.327 \\
AHH & 15 & 67.66 & 71.93 & 1.928 \\
RLS & 15 & 7.930 & 11.270 & 1.021 \\
Jumlah Penduduk (jiwa) & 15 & 71817 & 451916 & 621385.8
\end{tabular}

Berdasarkan Tabel 1 menunjukkan bahwa jumlah data dari setiap variabel atau nilai $\mathrm{N}$ berjumlah 15. Dari 15 data terdiri dari variabel tingkat pengangguran, pertumbuhan PDRB, AHH, RLS, dan jumlah penduduk. Dari masing - masing variabel memiliki nilai Minimum berturut-turut sebesar 2.640, -0.89, 67.66, 7.390, 71817. Nilai Maksimum berturut-turut sebesar 13.880, 0.17, 71.93, 11.270, 451916. Nilai Mean berturut-turut sebesar 6.481, $-0.007154,70.54,9.432,189530$. Kesimpulan dari masing-masing variabel yaitu penyimpangan data yang terjadi rendah dikarenakan memiliki nilai mean yang lebih tinggi daripada nilai standar deviasinya, sehingga penyebaran pada tiap variabel merata. Sedangkan pada variabel pertumbuhan PDRB dan jumlah penduduk penyebaran nilainya kurang merata dikarenakan memiliki nilai rata-rata lebih rendah ketimbang standar deviasinya. Hasil dari penyebaran nilainya tampak pada output berikut ini.

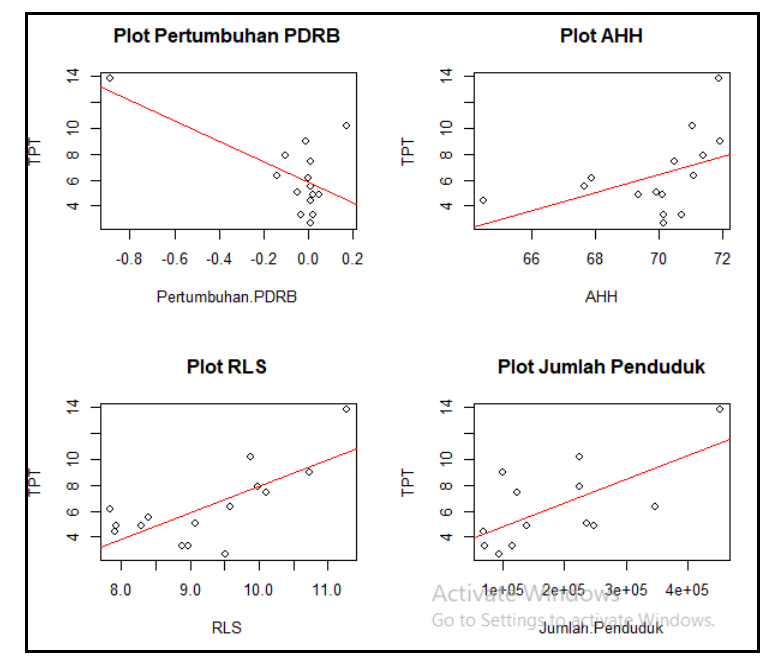

Gambar 3. Scatterplot penyebaran faktor tingkat pengangguran di Sulawesi Utara 2020. 
Berdasarkan scatterplot pada Gambar 3 dapat diketahui bahwa $\mathrm{X}_{1}$ memiliki kecenderungan hubungan negatif dengan gambar trend naik, sedangkan untuk $\mathrm{X}_{2}, \mathrm{X}_{3}$, dan $\mathrm{X}_{4}$ memiliki kecenderungan hubungan positif dengan gambar trend naik.

\section{Analisis Regresi Berganda}

Setelah dilakukan analisis data pada kasus ini dengan menggunakan Sofware $R$ Studio. Sehingga didapatkan hasil seperti berikut.

Tabel 2. Tabel analisis regresi linier berganda

\begin{tabular}{ccccc}
\hline & Estimate & Std.Error & $\mathbf{t}$-value & $\operatorname{Pr}(>|\mathbf{t}|)$ \\
\hline Intercept & 1.7560 & 2.5850 & 0.679 & 0.512 \\
$\mathrm{X}_{1}$ & 1.859 & 3.595 & 0.517 & 0.619 \\
$\mathrm{X}_{2}$ & -0.563 & 0.454 & -1.24 & 0.250 \\
$\mathrm{X}_{3}$ & 2.740 & 0.922 & 2.971 & 0.017 \\
$\mathrm{X}_{4}$ & $148 \times 10^{-8}$ & $727 \times 10^{-9}$ & 2.030 & 0.60768
\end{tabular}

Estimasi model dari hasil analisis pada Tabel 2 didapatkan:

$$
\widehat{Y}=1.7560+1.859 X_{1}-0.5634 X_{2}+2.740 X_{3}+0.00001476 X_{4}
$$

Pada Tabel 2 bahwa masih terdapat nilai p-value $>\alpha(0.05)$, sehingga untuk menentukan model terbaik dilakukan estimasi pemilihan model menggunakan metode Backward Elimination serta mencantumkan seluruh prediktor lalu dieleminasi satu persatu sampai tersisa hanya prediksi yang signifikan. Langkah awal dengan melakukan eliminasi variabel independen $\mathrm{X}_{1}$ karena variabel tersebut memiliki nilai $\mathrm{p}$-value yang terbesar, sehingga dilakukan analisis regresi berganda kembali dan didapatkan hasil seperti Tabel 3.

Tabel 3. Hasil regresi linier berganda Backward 1

\begin{tabular}{lllll}
\hline & Estimate & Std.Error & $\begin{array}{l}\mathbf{t}- \\
\text { value }\end{array}$ & $\operatorname{Pr}(>|\mathbf{t}|)$ \\
& & & 0.579 & 0.5768 \\
\hline Intercept & 1.375 & 2.375 & -1.18 & 0.2696 \\
$\mathrm{X}_{2}$ & -0.4693 & 0.3989 & 3.344 & $86 \times 10^{-}$ \\
$\mathrm{X}_{3}$ & 2.481 & 0.7419 & & 4 \\
& & & & 377 \\
$\mathrm{X}_{4}$ & 1214 & 4986 & 2.434 & 377 \\
& $\mathrm{x} 10^{-8}$ & $\mathrm{x} 10^{-9}$ & & $\mathrm{x} 10^{-4}$ \\
\hline
\end{tabular}

Estimasi model dari hasil analisis pada Tabel 3 didapatkan:

$\widehat{Y}=1.375-0.4693 X_{2}+2.481 X_{3}+0.00001214 X_{4}$ 
Berdasarkan Tabel 3 masih terdapat nilai p-value $>\alpha(0.05)$, sehingga dilakukan eliminasi variabel bebas $\mathrm{X}_{2}$ karena variabel tersebut memiliki nilai $\mathrm{p}$-value yang terbesar, sehingga dilakukan analisis regresi berganda kembali dan didapat hasil analisis seperti Tabel 4.

Tabel 4. Hasil perhitungan regresi linier berganda Backward 2

\begin{tabular}{lllll}
\hline & Estimate & Std.Error & $\begin{array}{l}\mathrm{t}- \\
\text { value }\end{array}$ & $\operatorname{Pr}(>|\mathbf{t}|)$ \\
& & & & \\
\hline \multirow{2}{*}{ Intercept } & -1.3580 & 5.003 & -2.72 & 2173 \\
& & & & $\mathrm{x} 10^{-5}$ \\
$\mathrm{X}_{3}$ & 1.901 & 0.5651 & 3.365 & 719 \\
& & & & $\mathrm{x} 10^{-4}$ \\
$\mathrm{X}_{4}$ & 1125 & 5022 & 2.240 & 0.049 \\
& $\mathrm{x} 10^{-8}$ & $\mathrm{x} 10^{-9}$ & & \\
\hline
\end{tabular}

Estimasi model dari hasil analisis pada Tabel 4 didapatkan:

$$
\widehat{Y}=-1.3580+1.901 \mathrm{X}_{3}+0.00001125 \mathrm{X}_{4}
$$

Hasil analisis pada Tabel 4 sudah signifikan semua yaitu dengan nilai p-value $<\alpha$ (0.05). Maka didapatkan estimasi model regresi linier berganda pada persamaan di atas. Kemudian melakukan uji validasi berupa uji overall, uji parsial, dan uji asumsi klasik.

\section{Uji Signifikansi Parameter}

Uji Overall (F-test)

Tabel 5. Uji Overall.

\begin{tabular}{cc}
\hline $\boldsymbol{P}$-value & $\boldsymbol{\alpha}$ \\
\hline 0,00128 & 0.05
\end{tabular}

Berdasarkan Tabel 5 diketahui $p$-value sebesar 0.00128 artinya $<\alpha(0.05)$ maka tolak $\mathrm{H}_{0}$ maka kesimpulan yang didapatkan adalah model layak digunakan.

\section{Uji Parsial (t-test)}

Tabel 6. Uji Parsial

\begin{tabular}{lll}
\hline \multicolumn{1}{c}{ Koefisien } & \multicolumn{1}{c}{$\boldsymbol{p}$-value } & \multicolumn{1}{c}{$\boldsymbol{\alpha}$} \\
\hline $\boldsymbol{\beta}_{\mathbf{3}}$ & 0,00719 & 0.05 \\
$\boldsymbol{\beta}_{\mathbf{4}}$ & 0,049 & 0.05
\end{tabular}

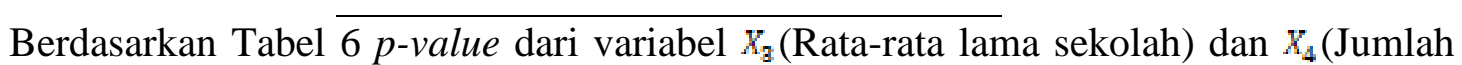
Penduduk) masing-masing sebesar 0.00719 dan $0.049<\propto(0.05)$ maka tolak $\mathrm{H}_{0}$, artinya 
bahwa variabel $X_{a}$ (Rata-rata lama sekolah) dan $X_{4}$ (Jumlah Penduduk) berpengaruh signifikan terhadap model.

\section{Koefisien Determinasi}

Tabel 7. Nilai Koefisien Determinasi

\begin{tabular}{c|c}
\hline \multicolumn{2}{c}{ Residual starndard error: } \\
1.807 on 10 degrees of freedom \\
\hline Multiple $R-$ & 0.7361 \\
Squared &
\end{tabular}

Dari hasil pembahasan, nilai $R$ square $\left(\mathrm{R}^{2}\right)$ nilainya yaitu 0.7361 maka variabel bebas dalam menerangkan variansi variabel dependen terbatas. Proporsi dari pengaruh variabel bebas yakni AHH, RLS, pertumbuhan PDRB, dan jumlah penduduk terhadap variabel terikat yakni tingkat pengangguran sebesar 73,61\% sedangkan sebesar $26.39 \%$ dipengaruhi variabel asing yang tidak ada di model regresi linier.

\section{Uji Asumsi Klasik}

\section{Uji Normalitas}

Tabel 8. Uji Normalitas.

\begin{tabular}{ccc}
\hline $\boldsymbol{P}$-value & D & $\boldsymbol{\alpha}$ \\
\hline 0.6845 & 0.14086 & 0.05
\end{tabular}

Berdasarkan Tabel $\overline{8 \text { p-value sebesar } 0.6845>\omega(0.05)}$ maka gagal tolak $\mathrm{H}_{0}$, maka kesimpulan yang diperoleh yaitu data berdistrbusi normal.

\section{Uji Autokorelasi}

Tabel 9. Uji Autokorelasi.

\begin{tabular}{ccc}
\hline $\boldsymbol{P}$-value & DW & $\boldsymbol{\alpha}$ \\
\hline 0.306 & 1.8246 & 0.05
\end{tabular}

Berdasarkan Tabel 9 p-value sebesar $0.306>\propto(0.05)$ maka gagal tolak $\mathrm{H}_{0}$, sehingga kesimpulan yang diperoleh adalah tidak ada autokorelasi.

\section{Uji Heteroskedastisitas}

Tabel 10. Uji Homoskedastisitas.

\begin{tabular}{cccc}
\hline $\boldsymbol{P}$-value & BP & df & $\boldsymbol{\alpha}$ \\
\hline 0.9601 & 0.081473 & 2 & 0.05
\end{tabular}


Berdasarkan Tabel 10 nila $p$-value $0.9601>\alpha(0.05)$ maka gagal tolak $\mathrm{H}_{0}$, kesimpulan yang diperoleh adalah asumsi kehomogenan variansi residual terpenuhi.

\section{Uji Multikolinearitas}

Tabel 11. Uji Multikolinieritas.

\begin{tabular}{ccc}
\hline Variabel & $X_{a}$ & $X_{4}$ \\
\hline VIF & 1.224096 & 1.224096
\end{tabular}

Berdasarkan Tabel 11 nilai VIF variabel Rata-rata Lama Sekolah (RLS) dan Jumlah Penduduk sebesar 1.224096. Dapat disimpulkan nilai VIF pada kedua variabel kurang dari (<) 10 artinya bahwa tidak terjadi multikolinieritas atau kedua variabel terbebas dari multikolinieritas.

Berdasarkan hasil uji asumsi yang telah dilakukan didapatkan kesimpulan pada tabel berikut ini.

Tabel 12. Kesimpulan Uji Asumsi.

\begin{tabular}{cc}
\hline Uji Asumsi & Kesimpulan \\
\hline Normalitas & Terpenuhi \\
Autokorelasi & Terpenuhi \\
Heterokedastisitas & Terpenuhi \\
Multikolinieritas & Terpenuhi \\
\hline
\end{tabular}

\section{Interpretasi Hasil Analisis}

Setelah dilakukan analisis regresi linier berganda pada data menggunakan program RStudio. Berikut merupakan model yang didapatkan.

$$
\widehat{Y}=-1.3580+1.901 \mathrm{X}_{3}+\mathbf{0 . 0 0 0 0 1 1 2 5 \mathrm { X } _ { 4 }}
$$

dengan $: \hat{Y}=$ Tingkat Pengangguran $\mathrm{X}_{3}=\mathrm{RLS} \mathrm{X}_{4}=$ Jumlah Penduduk

Dari hasil analisis menjelaskan pengaruh setiap variabel bebas pada variabel terikat. Jika koefisien regresi bernilai positif artinya variabel bebas terdapat pengaruh yang searah dengan variabel terikat, namun jika koefiesien regresi nilainya negatif maka variabel independen mempunyai pengaruh yang berlawanan arah dengan variabel dependen. Dapat disimpulkan bahwa:

a. Variabel RLS berpengaruh positif dan signifikan pada variabel Tingkat Pengangguran. Maka setiap kenaikan variabel RLS, pada variabel Tingkat Pengangguran juga meningkat sebesar $1.901 \%$. 
b. Variabel Jumlah Penduduk juga berpengaruh positif dan signifikan pada variabel Tingkat Pengangguran. Maka setiap kenaikan variabel Jumlah Penduduk, pada variabel Tingkat Pengangguran juga meningkat sebesar $0.00001125 \%$.

\section{KESIMPULAN}

Dari hasil analisis, maka didapatkan kesimpulan bahwa variabel Tingkat Pengangguran, AHH, dan RLS penyimpangan data yang terjadi rendah dikarenakan memiliki nilai rata-rata yang lebih besar daripada nilai standar deviasinya, sehingga penyebaran pada tiap variabel merata. Sedangkan pada variabel pertumbuhan PDRB dan jumlah penduduk penyebaran nilainya kurang merata dikarenakan memiliki nilai rata-rata lebih rendah daripada standar deviasinya. Selain itu, Variabel pertumbuhan PDRB dan AHH tidak berpengaruh signifikan terhadap tingkat pengangguran, sedangkan RLS dan Jumlah Penduduk berpengaruh positif dan signifikan terhadap tingkat pengangguran di Sulawesi Utara tahun 2020. Dari persamaan regresi linier berganda diperoleh bahwa setiap kenaikan variabel RLS, pada variabel Tingkat Pengangguran juga meningkat sebesar $1.901 \%$. Sedangkan setiap kenaikan variabel Jumlah Penduduk, pada variabel Tingkat Pengangguran juga meningkat sebesar $0.00001125 \%$.

\section{DAFTAR PUSTAKA}

Chalirafi, C., Anwar, K., \& Abdy Yusuf, M. (2020). Pengaruh Angka Harapan Hidup (Ahh) Dan Konsumsi Per Kapita Terhadap Pengangguran. Jurnal Ekonomi Dan Pembangunan, 11(2), 142-150. https://doi.org/10.22373/jep.v11i2.114

Ghozali, I. (2013). Aplikasi Analisis Multivariate dengan Program IBM SPSS 21 Update PLS Regresi (7th ed.). Badan Penerbit Universitas Diponegoro.

Ghozali, I. (2016). Aplikasi Analisis Multivariete Dengan Program (IBM SPSS). (8th ed.). Badan Penerbit Universitas Diponegoro.

Ghozali, I. (2018). Aplikasi Analisis Multivariate dengan Program IBM SPSS 25 (9th ed.). Badan Penerbit Universitas Diponegoro.

Hidayat, A. (2017). Pengertian dan Penjelasan Uji Autokorelasi Durbin Watson. https://www.statistikian.com/2017/01/uji-autokorelasi-durbin-watson-spss.html

Husila, S. (2019). Analisi Pengaruh Inflasi, Rata-Rata Lama Sekolah, Pertumbuhan Ekonomi Terhadap Pengangguran di Provinsi Sulawesi Selatan. Jurnal Ekonomi Dan Pembangunan, 1-23. http://eprints.unm.ac.id/14350/1/jurnal susi husila.pdf

Indayani, S., \& Hartono, B. (2020). Analisis Pengangguran dan Pertumbuhan Ekonomi sebagai Akibat Pandemi Covid-19. Jurnal Ekonomi \& Manajemen Universitas Bina Sarana Infoematika, 18(2), 201-208. https://ejournal.bsi.ac.id/ejurnal/index.php/perspektif/article/view/8581

Muslim, M. R. (2014). Pengangguran terbuka dan determinannya. 15, 171-181. 
Ningsih, S., \& Dukalang, H. (2019). Penerapan Metode Suksesif Interval pada Analsis Regresi Linier Berganda. Jambura Journal of Mathematics, 1(1). https://doi.org/10.34312/jjom.v1i1.1742

Samosir, N., Siagian, P., \& Bangun, P. (2014). Analisa Metode Backward Dan Metode Forward Untuk Menentukan. 2(4), 345-360.

Statistik, B. P., \& Gorontalo, P. (2020). Keadaan Ketenagakerjaan Provinsi Gorontalo Agustus 2020 Agustus 2020: Tingkat Pengangguran Terbuka ( TPT ). 19(60), 1-10.

Sukirno, S. (2008). Mikroekonomi: Teori Pengantar (3rd ed.). PT Raja Grafindo Persada. 